\title{
Acceptability of genetically engineered algae biofuels in Europe: opinions of experts and stakeholders
}

\author{
Jessica Varela Villarreal ${ }^{*} \mathbb{D}$, Cecilia Burgués and Christine Rösch
}

\begin{abstract}
Background: The development of alternative pathways for sustainable fuel production is a crucial task for politics, industry and research, since the current use of fossil fuels contributes to resource depletion and climate change. Microalgae are a promising option, but the technology readiness level (TRL) is low and cannot compete economically with fossil fuels. Novel genetic engineering technologies are being investigated to improve productivity and reduce the cost of harvesting products extracted from or excreted by microalgae for fuel production. However, high resource efficiency and low costs alone are no guarantee that algae fuels will find their way into the market. Technologies must be accepted by the public to become valuable for society. Despite strong efforts in algae research and development, as well as political commitments at different scales to promote algae biofuels for transport sectors, little is known about public acceptance of this alternative transport fuel. Despite the advantages of algae technology, genetically engineered (GE) microalgae can be controversial in Europe due to risk perception. Therefore, the aim of this study was to investigate, for the first time, the knowledge and views of European experts and stakeholders on the conditions and requirements for acceptability of GE microalgae for next generation biofuel production.

Results: The results of the survey-based study indicate that the majority of the respondents believe that GE algae biofuels could provide strong benefits compared to other fuels. The majority would choose to be final consumers of engineered algae biofuels, if there is clear evidence of their benefits and open communication of potential risks. They believe that closed production systems with high security standards and rigorous risk assessment should be applied to avoid unintended impacts on humans and nature. Some respondents, however, are not convinced about the need to alter natural occurring algae strains to increase productivity, arguing that there is a huge unexplored variety, and that the consequences of using genome editing are still unknown.

Conclusions: This evaluation of the opinions held by European experts and stakeholders regarding GE algae biofuels provides valuable and differentiated insights, both for future research and for the development of feasible socio-technical algae systems for next generation biofuel production. The identified conditions and requirements for achieving public acceptability can support the (re-)design of this innovative technology and adaptation of the framework conditions towards the implementation of algae biofuels in Europe.
\end{abstract}

Keywords: Genetically modified organisms, Gene editing, Algae, Biofuel, Social perception, Acceptance, Risk perception, Survey

*Correspondence: jessica.villarreal@kit.edu

Institute for Technology Assessment and Systems Analysis (ITAS), Karlsruhe Institute of Technology (KIT), Karlstr.11, 76133 Karlsruhe, Germany

\section{Background}

Sustainable biofuel alternatives have been deeply investigated for decades in order to replace fossil fuels for future mobility [29]. The potential of using microalgae 
to produce biofuels continues to be investigated. Algae technology is economically unsustainable and can only contribute to mitigating climate change under certain conditions [28]. In terms of potential to reduce costs, the most important common factor is the increment of average productivity (yield) [24]. Although in recent years, some higher yields have been achieved by different cultivation strategies using natural algal strains such as Tetraselmis suecica and Nannochloropsis oculata [33, 38], algal biofuels still cannot economically compete with fossil fuels [3, 10]. Ketzer et al. [13] concluded in their review that a higher energy return of investment (EROI) could be achieved, from a biological point of view, by enhancing the efficiency of photo-conversion, which would lead to higher biomass and energy yields. The research focus is currently therefore to increase and modify the accumulation or release of energy products or their precursors (e.g., lipids, alcohols, hydrocarbons) in photosynthetic microalgae through genetic engineering. Although the application of genetic engineering to improve energy production phenotypes in eukaryotic microalgae is in its infancy, significant advances in the development of genetic manipulation tools have been achieved recently with microalgal model systems, and are being used to manipulate central carbon metabolism in these organisms [26]. It is likely that many of these advances can be extended to industrially relevant organisms, and that this will be a major research advance concerning the commercialization of algae biofuels $[7,10]$.

Precise CRISPR/Cas9-based genome editing of industrial algal strains such as Nannochloropsis, which accumulates oil as a source of plant-like oils for biofuel production during nitrogen deprivation, have been conducted by Wang et al. [34], opening opportunities for microalgae-based biotechnological applications. Metabolic engineering of Chlamydomonas reinhardtii was presented as an option to be optimized for biofuel production, due to the achievement of higher yields of terpenoids [36]. Recently, a joint study also pointed Chlamydomonas reinhardtii as the next chassis for sustainable synthetic biology [6]. Furthermore, protein engineering has been recently used to enhance isobutanol production in the unicellular cyanobacterial strain Synechocystis PCC 6803 [21, 19, 20, 37].

The use of GE microalgae strains for the release of biofuel precursors to the culture broth for direct separation without cell harvesting has been thoroughly investigated in the Photofuel project (http://www.photofuel. eu). Metabolic engineering strategies were employed by Liu, Miao et al. [20] to generate 1-butanol producing Synechocystis. After the selection of enzymes and promoters, $836 \mathrm{mg} \mathrm{L}^{-1}$ of 1-butanol were produced in a flask. By optimizing the cultivation condition, an in-flask titer of $2.1 \mathrm{~g} \mathrm{~L}^{-1}$ and a maximal cumulative titer of $4.7 \mathrm{~g} \mathrm{~L}^{-1}$ were observed in the long-term cultivation. These strains with enhanced or modified metabolic activity show great potential for biotechnological exploitation. Since there is a highly controversial general debate around agricultural genetic engineering in Europe [5, 17], it cannot be ruled out that there might be similar concerns about the impact of GE microalgae on the environment and human health. Whether such a debate will arise on the topic of algae, and how this is addressed, will play a key role in implementation and commercialization of engineered microalgae, including their application for biofuel production [4].

The present study was conducted within the European Union (EU) H2020 project Photofuel, in order to investigate the conditions and requirements for the implementation of a novel technology for engineered microalgae biofuel production. The objective of the work was to gain insights into the opinions and attitudes of European experts and stakeholders regarding their knowledge, perception and views of this technology as well as on their conception regarding its public acceptability.

\section{Results}

The survey scored 130 valid responses from across the EU on 16 different questions.

\section{Descriptive statistical analysis \\ 1. Sociodemographic profile}

The sociodemographic profile of the respondents (Fig. 1) shows a high response rate from males (78\%). Respondents had a high educational level; $62 \%$ had a Ph.D., and only $6 \%$ did not have a University degree. A high number of respondents had experience in the algae industry (71\%). Most worked in education or academia (51\%), followed by industry, consulting or management (33\%). The majority of respondents (73\%) were between 31 and 61 years. Answers from 17 of the $27 \mathrm{EU}$ countries and from the former EU country United Kingdom, were recorded. Most of the respondents were from Germany $(26 \%)$, followed by Italy (17\%), Spain (11\%), France (8\%), Belgium (8\%), the Netherlands (6\%) and Portugal (5\%). A low percentage (between $3 \%$ and $1 \%$ ) of respondents were from the United Kingdom, Sweden, Poland, Ireland, Greece, Finland, Czech Republic, Austria, Slovenia, Hungary and Denmark. No response was obtained from Bulgaria, Croatia, Cyprus, Estonia, Latvia, Lithuania, Luxembourg, Malta, Romania and Slovakia.

Plots from RStudio (not shown) exposed two main groups: the most noticeable group belonged to the field of education or academia, in the age group of 31 to 60 years; 

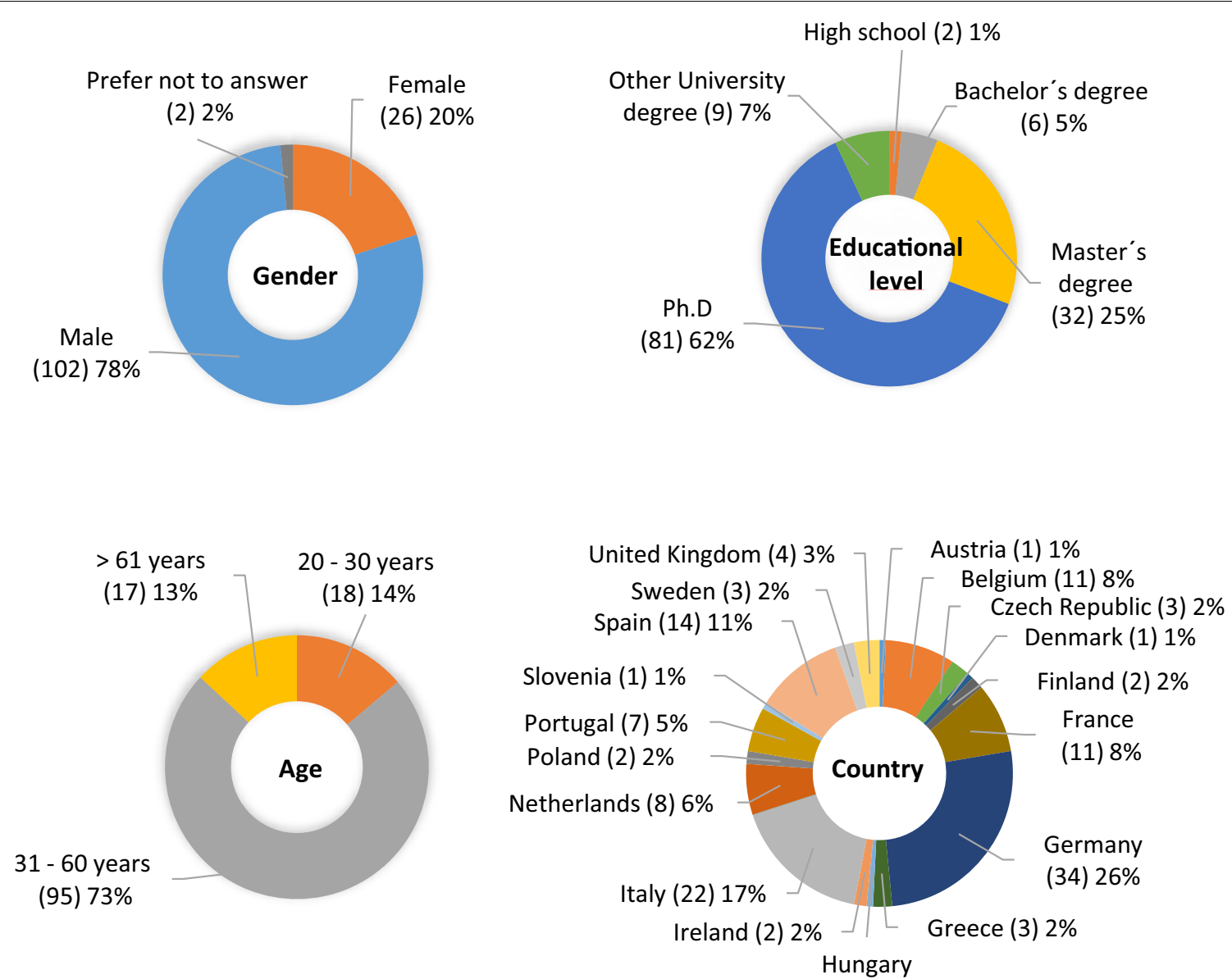

Other (12) $9 \%$

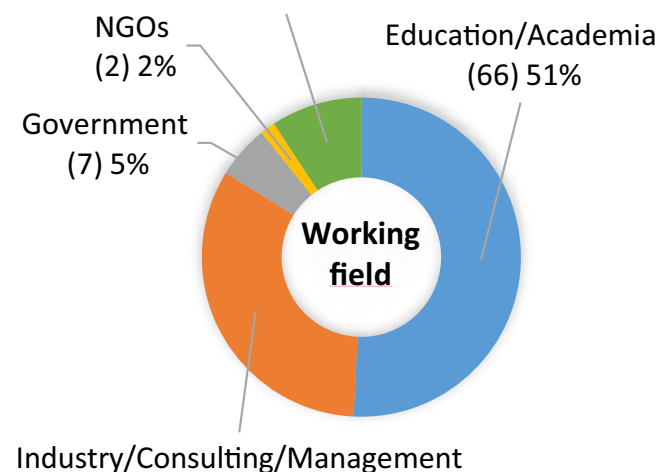

(43) $33 \%$

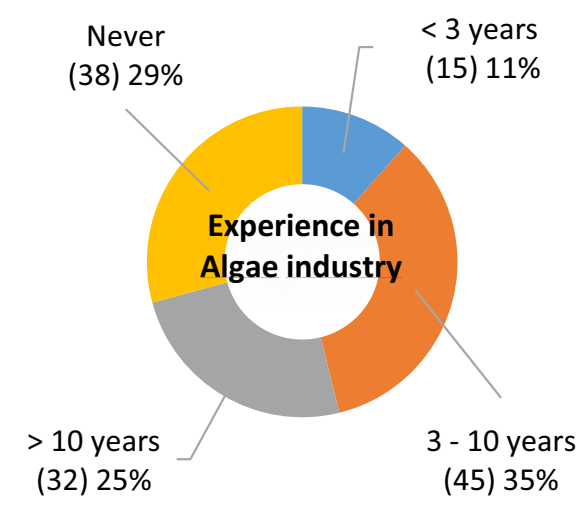

Fig. 1 Sociodemographic data (absolute results are shown in brackets)

the second group belonged to industry, consulting or management, and to the same age group. In both groups, most respondents were males, although the number of females was higher in the education or academia group.

\section{Perceptions of expected benefits and risks of GE algae biofuel}

Most respondents perceived that the expected benefits of GE algae biofuel were high, in contrast to fossil fuels, established biofuels and even to natural algae biofuels (Fig. 2). They were noticeably higher when compared 


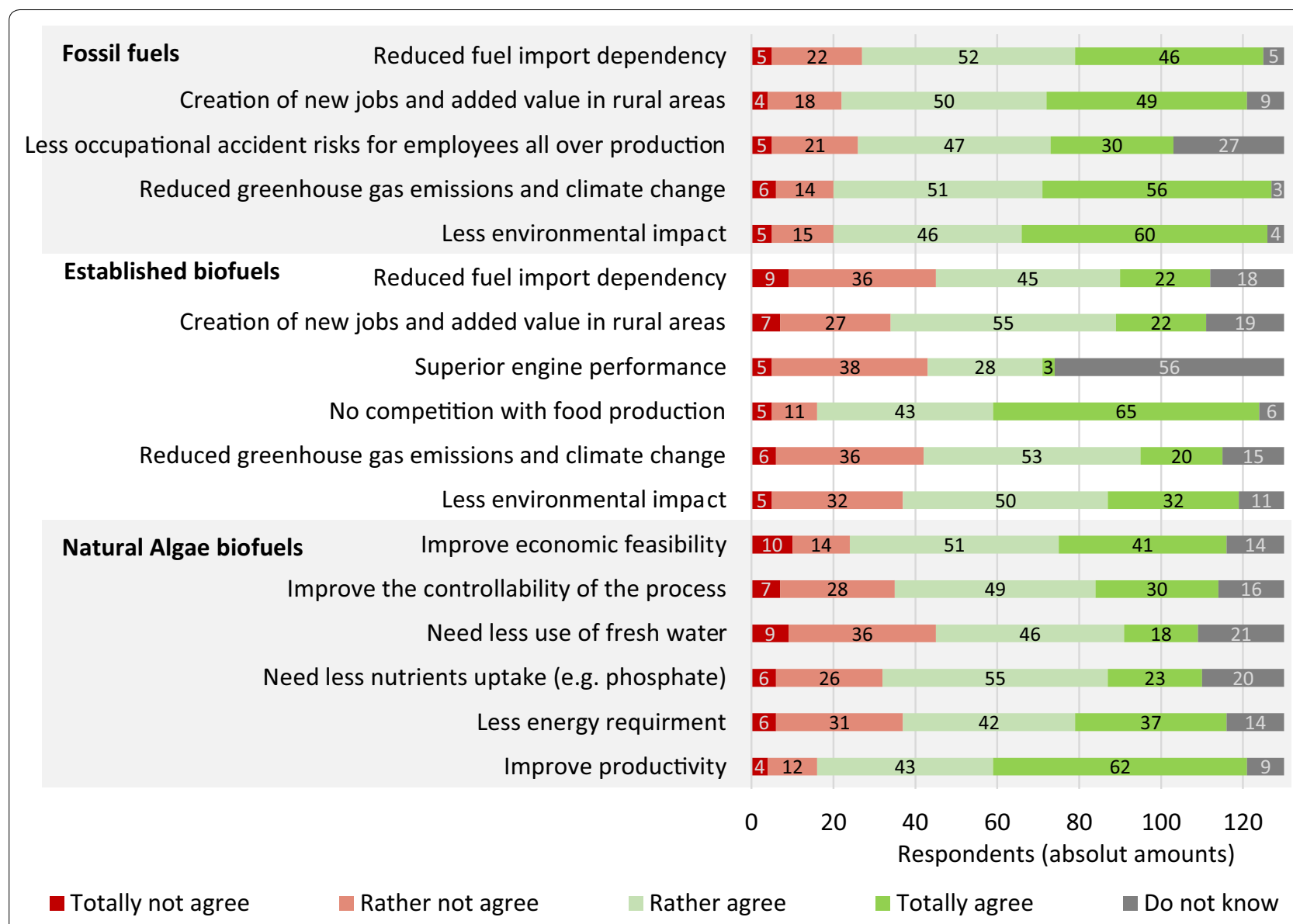

Fig. 2 Perceptions of respondents about expected benefits of GE algae biofuel among fossil fuels, established biofuels and natural algae biofuels

to fossil fuels, especially in the options that referred to environmental issues. In the case of the expected benefits of GE algae biofuel among established biofuels, the highest agreement level was for "No competition with food production". The lowest was for "Superior engine performances", but in this case the highest amount of "Do not knows" was also observed. The expected benefits of GE algae instead of natural strains are also significant, "Improvement of economic feasibility" and "The improvement of productivity" being the most supported options.

When respondents were asked about choosing to replace fossil fuels, at least partially, with GE algae biofuel in order to use fewer limited resources and reduce climate change, their answer tended to be positive (31\% totally agreed, and $40 \%$ rather agreed). This indicates that partially replacing fossil fuels with GE algae biofuel could be a positive option to mitigate climate change.

Considering the perception of the general risks (i.e., health, environment and accidents) of different fuels and power sources that could be used for future mobility (Fig. 3), 92\% of the respondents indicated fossil fuels as the most alarming case, followed by established biofuels (48\%). Most of the respondents (92\%) considered wind power, hydropower and solar photovoltaic power as the most harmless options, followed by $80 \%$ of the respondents who believe that GE algae biofuel would also be a harmless alternative. Higher amounts of "Do not knows" were observed for GE algae biofuel (5\%) and Hydropower (4\%), indicating that people are less informed about these topics.

\section{Perceptions of social acceptance of GE algae biofuel}

Respondents believe that GE algae biofuel will have a medium (50\%) to high (11\%) general acceptance in the EU (Fig. 4), although a relatively high percentage think the opposite.

When asking if this acceptance would change with the use of novel precise gene-editing techniques instead of traditional genome modification techniques, an average perception between no difference $(38 \%)$ and a slightly higher acceptance (35\%) was obtained (Fig. 5).

Respondents were asked if they thought gene-editing should fall under current GMO regulation. A clear 


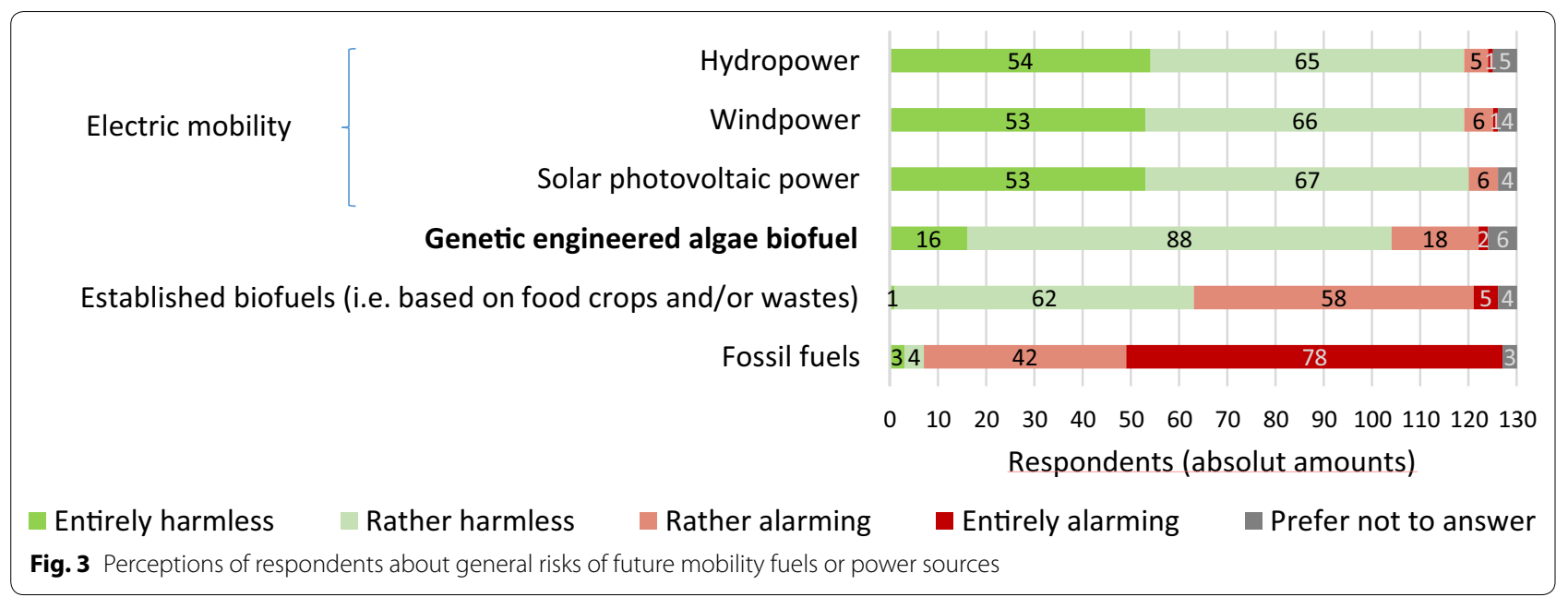
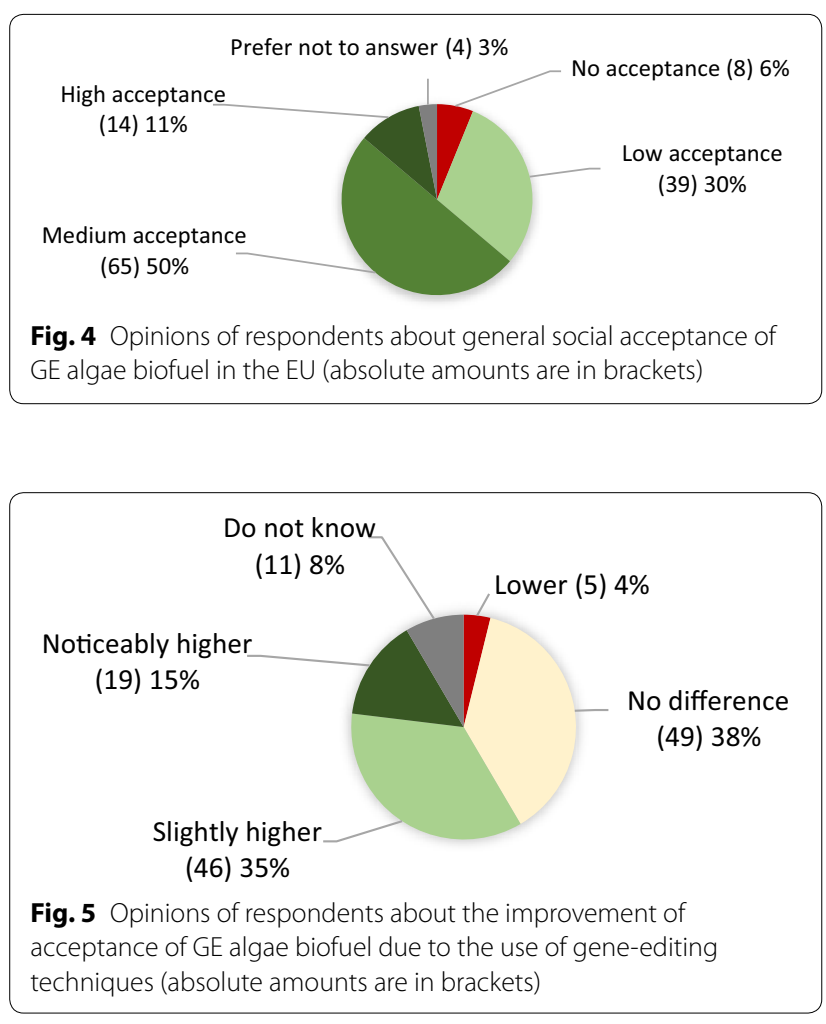

difference of opinions was observed (Fig. 6), although $53 \%$ gave a positive answer, $36 \%$ gave a negative answer and $11 \%$ did not know. This question had the most "Do not knows" within the social acceptance section of the questionnaire.

\section{Personal attitudes as consumers}

The majority of the respondents (72\%) would choose to be final consumers of GE algae biofuel, while $18 \%$ did not

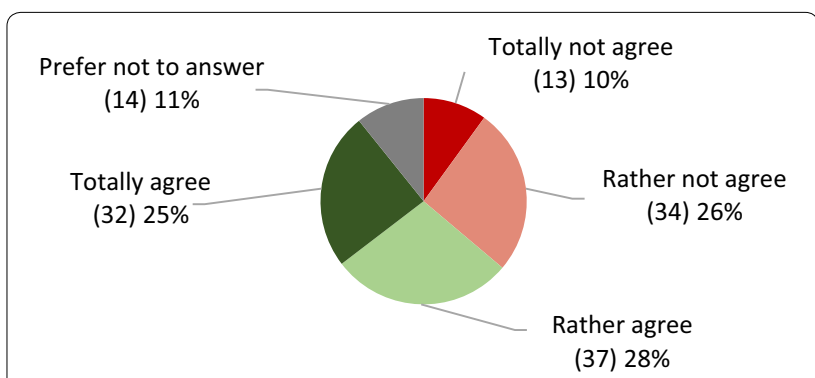

Fig. 6 Opinions of respondents about not regulating gene-editing as GMO (absolute amounts are in brackets)

know, and $10 \%$ answered negatively. Their willingness to spend more money on GE algae biofuel if higher engine performances compared to those of established biofuels were achieved, and in cases where more environmental advantages were achieved compared to fossil fuels are shown in Fig. 7. If GE algae biofuel could achieve higher engine performances, then $21 \%$ of respondents answered that they were willing to pay $5-10 \%$ more money; but the same percentage answered that they were not prepared to spend more money. Finally the same percentage answered that they did not know how much more money they would spend. In cases where biofuel had environmental advantages compared to fossil fuels, the highest percentage of respondents $(32 \%)$ answered that they were willing to spend $5-10 \%$ more money. When compared with the previous question, significantly fewer respondents answered negatively, and there were fewer respondents who did not know how much more money they would be willing to spend. In general, for the higher ranges of money to be spent, it seems people are more interested in environmental care than in getting better engine performances. 


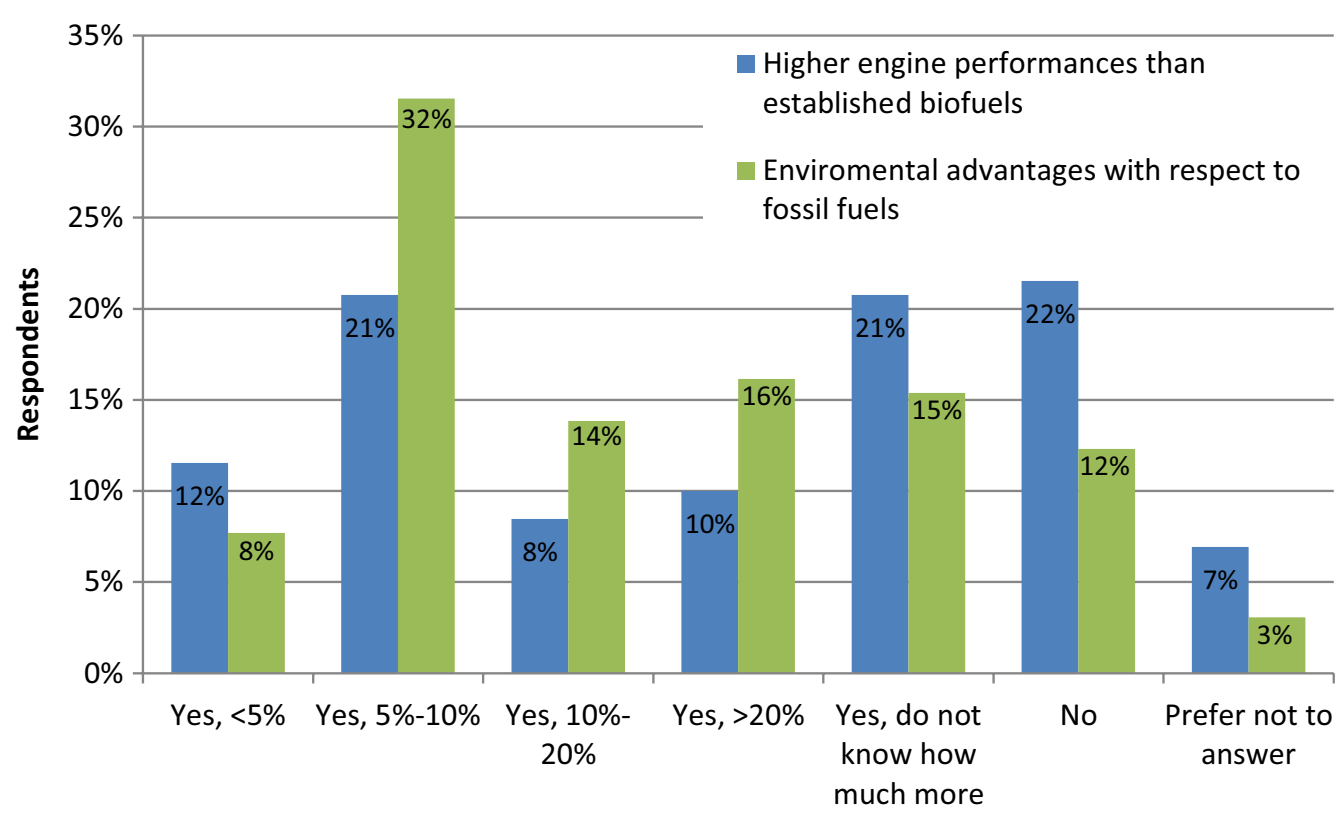

Fig. 7 Willingness to spend more money on GE algae biofuel if higher engine performances than those for established biofuels (blue) were achieved, and if environmental advantages compared to fossil fuels (green) were attained

\section{Individual suggestions}

Respondents were asked how to improve social acceptance of GE algae biofuel (Fig. 8). The most selected options were to clearly communicate the risks and benefits of genome engineering technology (62\%), to have clear evidence of benefits (61\%), and to use closed production systems with high security standards (59\%). The second place options were to carry out

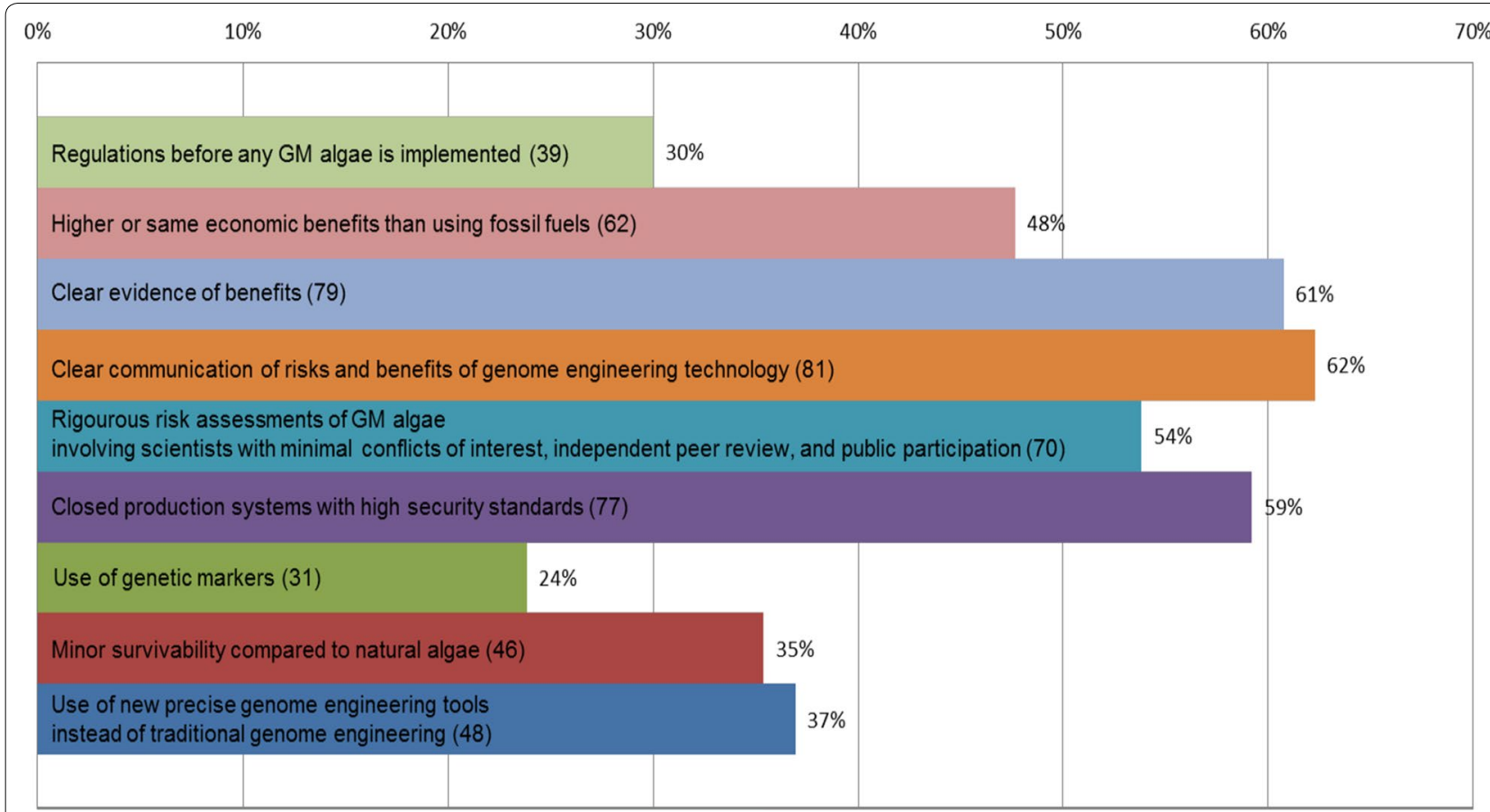

Fig. 8 Suggestions of the respondents on how to improve social acceptance of GE algae biofuel 
rigorous risk assessments of genetically modified (GM) algae, involving scientists with minimal conflicts of interest, independent peer review, and public participation (54\%), and to achieve higher or equal economic benefits than using fossil fuels (48\%). The options with lowest interest were the use of genetic markers in order to identify the presence of GE algae as well as the flow of a particular genome engineered trait, if released into the environment (30\%), and the necessity for regulations before any genome engineered species is released (24\%). However, the percentages for these options were not low.

\section{Inductive statistical analysis}

Inductive statistical tests were done to seek possible relationships between the variables, as shown in Fig. 9. Only statistically significant results $(p$ values $<0.05)$ are shown in Tables 1, 2 and 3.

Table 1 shows Spearman's rank correlation coefficients between sociodemographic ordinal variables and opinion ordinal variables. Although some $p$ values lower than 0.05 were found, indicating that the relationships are statistically significant, none of the Spearman correlation coefficients had high values, indicating weak relationships between the variables. These weak relationships were the following:

1. The younger the respondents the more they agreed that the expected benefits of GE algae biofuel, compared to established biofuels, include less environmental impact and reduced greenhouse gas emissions and climate change.

2. People with a higher educational level agreed more that the expected benefits of GE algae biofuel, compared to established biofuels, include less environmental impact and new rural jobs.

3. People with a higher educational level were more skeptical that the expected benefits of GE algae biofuel, compared to established biofuels, include reduced greenhouse gas emissions; and, compared to natural strains, a reduced energy demand.

Table 2 shows only $p$ values $<0.05$ after Chi-square test was done between sociodemographic ordinal variables and opinion nominal variables, and their respective Cramer's V values. Following the rule for the interpretation of Cramer's V values, the following moderate relationships were found:

1. Respondents older than 31 years seemed to have a higher acceptance of using new precise genome editing tools instead of traditional genome engineering.
2. Respondents younger than 30 and older than 60 years (approx. 77\%) believed that the use of closed production systems with high security standards should be a priority.

3. A tendency was observed, where the higher the educational level of respondents was, the higher willingness they had to be final GE algae biofuel consumers, but also the number of respondents who answered 'Do not know' to this question increased with educational level.

4. Respondents who had never been active in the algae industry and respondents with more than 10 years of experience in the algae industry showed a lower tendency for willingness to be final GE algae biofuel consumers. The main difference between these two groups was that the respondents who had never been active in the algae industry also had a greater percentage that replied, 'Do not know'.

The only strong relationship was the following:

- Respondents with a higher educational level gave more importance to the clear communication of risks and benefits of genome engineering technology.

Table 3 shows only $p$ values $<0.05$ after Chi-square test was done between sociodemographic nominal variables and opinion ordinal variables, and their respective Cramer's $\mathrm{V}$ values. Following the rule for the interpretation of Cramer's V values, the following moderate relationships were found:

1. Although most female respondents believe that hydropower is rather harmless, they are cautious in affirming that hydropower is an entirely harmless source of power.

2. Although most of the respondents from every professional field had a higher tendency to believe that one of the benefits of GE algae biofuel compared to fossil fuels is the lack of competition with food production, the group of respondents working in education or academia had the highest tendency for agreement (37.9\% rather agreed, and 53\% totally agreed).

3. Most respondents tended to agree that one of the benefits of using GE algae biofuel compared to natural strains would be the requirement for less energy in its production, but in the group of respondents working in education or academia there were more respondents that did not know, (14.6\%) while the respondents working in industry were more skeptical of this benefit (2.3\% totally not agreed and $41.9 \%$ rather not agreed). 


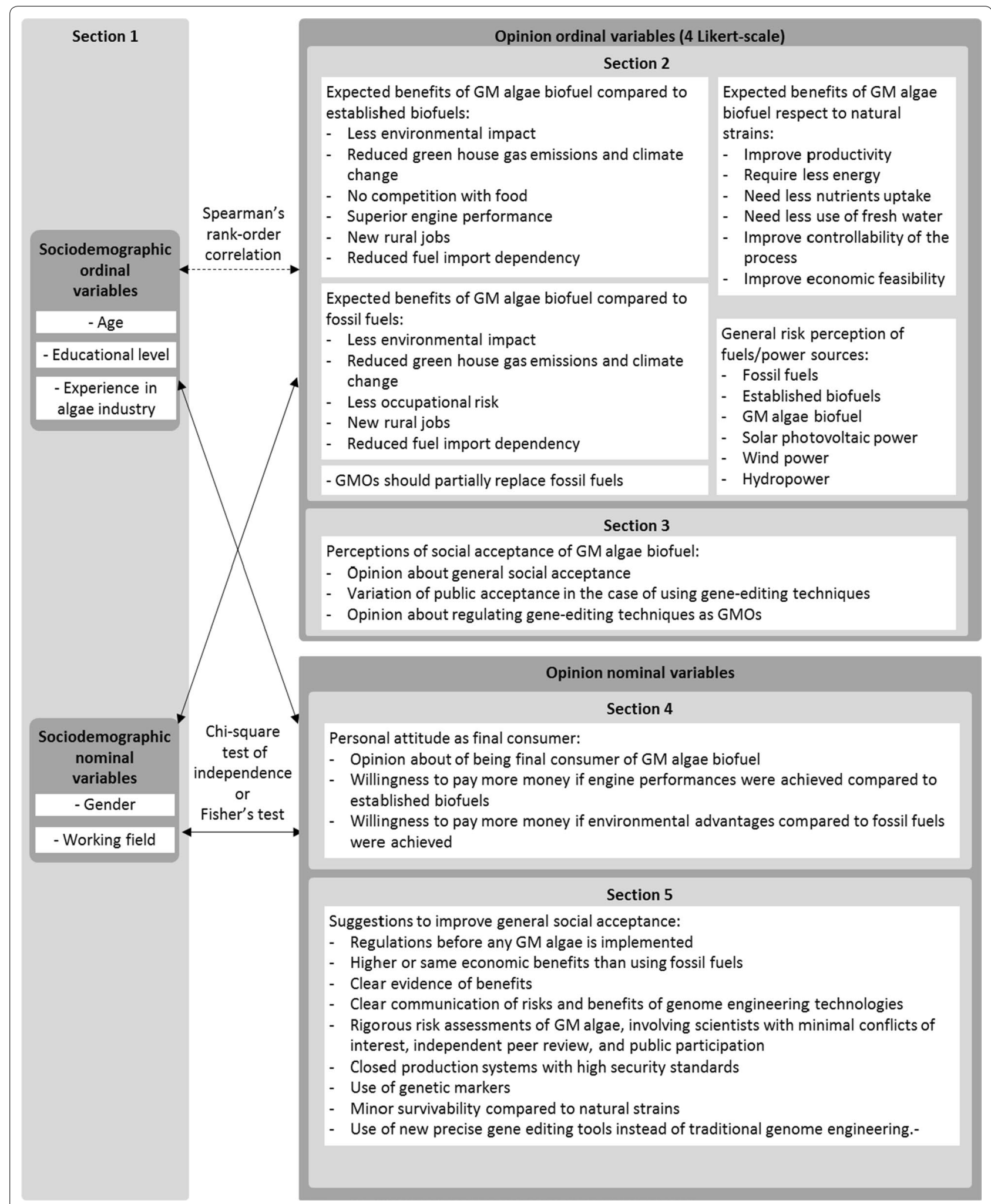

Fig. 9 Summary and overview of variables and the statistic tests performed to find statistical relationships 
Table 1 Correlation coefficients and $p$ values (only $p$ values $<0.05$ are shown) after Spearman's rank order between sociodemographic ordinal variables and opinion ordinal variables

\begin{tabular}{|c|c|c|c|}
\hline $\begin{array}{l}\text { Sociodemographic ordinal } \\
\text { variables }\end{array}$ & Opinion ordinal variables & $\begin{array}{l}\text { Spearman's rank order } \\
\text { coefficient }\end{array}$ & $p$ value \\
\hline \multirow[t]{3}{*}{ Age } & Expected benefits of GE algae biofuel compared to established biofuels & & \\
\hline & Less environmental impact & -0.17 & 0.025 \\
\hline & Reduced GHG emissions and climate change & -0.19 & 0.023 \\
\hline \multirow[t]{6}{*}{ Educational level } & Expected benefits of GE algae biofuel compared to established biofuels & & \\
\hline & Less environmental impact & 0.02 & 0.044 \\
\hline & Reduced GHG emissions and climate change & -0.03 & 0.001 \\
\hline & New rural jobs & 0.06 & 0.040 \\
\hline & Expected benefits of GE algae biofuel compared to natural strains & & \\
\hline & Require less energy & -0.03 & 0.021 \\
\hline
\end{tabular}

Table 2 Chi-square test correlations ( $p$ values $<0.05$ ) and respective Cramer's V values between sociodemographic ordinal variables and opinion nominal variables

\begin{tabular}{|c|c|c|c|}
\hline Sociodemographic ordinal variables & Opinion nominal variables & $\begin{array}{l}x^{2} \text {-test } \\
(p \text { value })\end{array}$ & Cramer's V \\
\hline \multirow[t]{3}{*}{ Age } & Suggestions to improve general social acceptance & & \\
\hline & Closed production systems with high security standards & 0.041 & 0.221 \\
\hline & Use of new precise gene editing tools instead of traditional genome engineering & 0.044 & 0.220 \\
\hline \multirow[t]{4}{*}{ Educational level } & Personal attitude as final consumer & & \\
\hline & Opinion about being final consumer of GE algae biofuel & 0.037 & 0.251 \\
\hline & Suggestions to improve general social acceptance & & \\
\hline & Clear communication of risks and benefits of genome engineering technologies & 0.004 & 0.346 \\
\hline \multirow[t]{2}{*}{ Experience in algae industry } & Personal attitude as final consumer & & \\
\hline & Opinion about being final consumer of GE algae biofuel & 0.024 & 0.236 \\
\hline
\end{tabular}

Table 3 Chi-square test correlations $(p$ values $<0.05)$ and respective Cramer's V values between sociodemographic nominal variables and opinion nominal variables

\begin{tabular}{|c|c|c|c|}
\hline $\begin{array}{l}\text { Sociodemographic nominal } \\
\text { variables }\end{array}$ & Opinion nominal variables & $\begin{array}{l}\mathrm{X}^{2} \text {-test } \\
\text { ( } p \text { value })\end{array}$ & Cramer's V \\
\hline \multirow[t]{2}{*}{ Gender } & General risk perception of fuels/power sources & & \\
\hline & Hydropower & 0.034 & 0.285 \\
\hline \multirow[t]{10}{*}{ Working field } & Expected benefits of GE algae biofuel compared to established biofuels & & \\
\hline & No competition with food & 0.011 & 0.246 \\
\hline & Expected benefits of GE algae biofuel compared to natural strains & & \\
\hline & Require less energy & 0.016 & 0.242 \\
\hline & Improve the controllability of the process & 0.050 & 0.225 \\
\hline & Perceptions of social acceptance of GE algae biofuel & & \\
\hline & Opinion about regulating gene-edited organisms as GMOs & 0.024 & 0.236 \\
\hline & General risk perception of fuels/power sources & & \\
\hline & Fossil fuels & 0.022 & 0.237 \\
\hline & Wind power & 0.002 & 0.267 \\
\hline
\end{tabular}

4. Most respondents tended to agree in affirming that one of the benefits of using GE algae biofuel compared to natural strains would be improved control- lability of the process. The group of respondents working in education or academia agreed more (40.9\% rather agreed and $25.8 \%$ totally agreed), while 
the group of respondents working in industry had a higher percentage that did not know (14\%).

5. Most respondents working in education or academia, and also in industry, tended to agree in affirming that organisms with small genetic changes achieved by gene-editing techniques, should not fall under the current regulations for GMOs. 57.1\% of respondents working for the government did not know.

6. Although more than $90 \%$ of the respondents believe that the general risk of using fossil fuels is alarming, some respondents working in education and academia were skeptical about this with $4.5 \%$ who answered that it was rather harmless, and $4.5 \%$ that answered it was entirely harmless. While $100 \%$ of respondents working in the government agreed that this source of power is alarming (rather alarming $14.3 \%$, and entirely alarming $85.7 \%$ ).

7. Although most respondents believe that wind power is harmless (more than $88 \%$ ), $7 \%$ of the respondents working in industry rated this energy source as harmful (4.7\% rather alarming and 2.3\% entirely alarming). While $100 \%$ of respondents working in the government agreed that this source of power is harmless (rather harmless $57.1 \%$, and entirely alarming 42.9\%).

\section{Discussion}

First and second-generation biofuels cannot meet global demands in a sustainable way [1]. Therefore, third generation biofuels produced with microalgae are considered to play a crucial role in achieving long-term climate policy objectives in the mobility sector. However, the production of algal fuel is not yet economically feasible nor sustainable regarding the demand of energy and the release of greenhouse gas emissions [13, 28]. Research and development is trying to overcome the techno-economic and ecological obstacles that hinder the implementation of algae biofuel production for sustainable mobility. New methods of genetic engineering, such as genome editing, can foster the achievement of this objective by increasing algae productivities and yields and by facilitating the release of fuels or fuel precursors into the cultivation media to make the process and respective fuel harvesting more efficient. Scientists have discovered new ways of using GE yeast for biofuel production, making yeasts more tolerant to the self-produced ethanol [15].

In the EU, research with GE algae is restricted to authorized laboratories and pilot plants, which need safeguard precautions to avoid any risks that could eventually result from the uncontrolled release of these GE algae into the environment. Since the process of producing fuels with GE algae is at a low TRL level, there is no information available about the perception of GE algae by experts and stakeholders. Our results indicate that there is no evidence about possible concerns or even opposition to the technology. This could be related to the fact that the media have not reported on it and knowledge about GE algae is not yet widespread. Another reason could be that the use of GE algae for biofuel production would be to replace the unpopular first generation biofuels. There is evidence that in contrast to GE applied in food production, there are no such concerns for GE crops, which are used to produce first generation bioethanol and biodiesel from starch (e.g., corn) and vegetable oil feedstock (e.g., soybean) [32]. Particularly, North and South American countries are large-scale producers of GE corn and soya that are not only used for food and feed, but also for fuel production. Moreover, research on GE is ongoing for second-generation bioethanol production from cellulosic biomass, which is both abundant and renewable, and a promising alternative to bioethanol produced with food crops. Plant genetic engineering promises to have a key role in decreasing biofuel production costs by deconstructing plant cell-wall polysaccharides by higher levels of cellulases and hemicellulases, suppressing lignin biosynthesis enzymes, which reduce the need for pretreatment, or by increasing the content of polysaccharides or the overall plant biomass [31].

Although our results indicate a higher preference for GE algae biofuel compared to first generation biofuels, it cannot be concluded that people will purchase the product once algae biofuel is on the market, and even pay more money for it, compared to other fuels. Since there is an intensive debate on sustainable mobility in general and a trend to ban cars with combustion engines, it is not surprising that mobility provided by green electricity based on hydro, wind and solar power is regarded as even more desirable due to lack of emissions and climatefriendliness. The results from this survey are compatible with the findings of Moula et al. [23] and Kubik [14]. Moula et al. [23] found that only $60 \%$ of respondents are willing to switch towards purchasing second-generation biofuels, and that car owners responding to the question about the ideal fuel would prefer electricity (60\%) over hydrogen (20\%) and hybrid (20\%). Kubik [14] found that when asked to choose among ethanol, hydrogen and electricity, the respondents of a US National Renewable Energy Laboratory survey rated ethanol as the worst fuel to be used in personal vehicles once gasoline is no longer available. Respondents tended to have environmental concerns as their primary motivation. Data suggests that the American public is largely unaware of biofuels, being an important finding that has been used to explain the sometimes reported low levels of support [35]. As Einsiedel and Eastlick [8] reported, citizens do not exclusively rely upon knowledge when forming opinions about 
political and scientific issues. Instead, individuals will often rely on heuristic shortcuts to make sense of complex and controversial issues.

Adeniyi et al. [1] found that fast-track algae biofuel production could be a feasible midterm solution to replace fossil transportation fuels in trucks and airplanes which will not be fueled by renewable electricity in the next 10 to 20 years. Moreover, fuel blends with algal biofuel give positive results on combustion and emission (www.photo fuel.eu). The opinion of the experts and stakeholders in our study support the statement of Adeniyi et al. [1]. A high fraction of experts $(71 \%)$ expressed that a partial replacement of fossil fuels with GE algae biofuel could be a positive option to mitigate climate change. A sustainable future of mobility should not be viewed as the end of the internal combustion engine, currently the main source of vehicular propulsion [18]. The development and use of more sustainable and environmentally friendlier options, like GE algae biofuel, should therefore be considered for the transformation phase.

In the EU, the use of GE crops and GMOs in agriculture is subject to extensive restrictions since public opposition to GM technology is widespread [9]. There is also opposition in the United States. In a representative survey of U.S. residents, $64 \%$ opposed GM, and $71 \%$ of GM opponents (45\% of the entire sample) were "absolutely" opposed-that is, they agreed that GM should be prohibited no matter the risks and benefits. These absolute opponents predicted support for legal restrictions on GE foods, even after controlling for explicit risk-benefit assessments. This research suggests that many opponents are evidence-insensitive and will not be influenced by arguments about risks and benefits [30].

Nowadays, the production of biofuels with GE algae still has not been a focus of public opinion, and no significant negative media reports or public opinions have been found. But if large-scale production of algal fuel was implemented, it is not unlikely that opposition could arise due to the general controversial debate on genome editing in plant breeding and microorganisms. Since no method of genetic modification is without the possibility of unintended effects, genetic engineering in general and the new technique of genome editing are likely to be subject to the same underlying factors of information processing and risk perception by the public, media and individuals that have been found across multiple other emerging technologies. Most of our survey respondents have an academic background, and it is possible that the results would be different for the general public.

If a technology is merely perceived as similar to the incumbent one, consumers will not be motivated to adopt it. This is especially true when an innovation is more expensive than the preceding technology [27].
Our results reveal respondents' expectations that GE algae biofuels could provide strong benefits among other fuels, mainly due to the reduction of environmental impacts in general, and climate change and land use competition. However, this expectation cannot be met by science today. The same is true for the statement that GE algae are superior to natural strains and can improve the environmental compatibility and economic viability of algae biofuels. There is evidence at lab and pilot scale about their superiority and lack of significant disadvantages, but this has to be proven at a commercial scale, since this is required for the genetic stability of GE algae.

Even if algae can keep the promises of providing additional benefits to humans and nature, this does not necessarily lead to public acceptance. Even crops with great potential to combat major health problems due to malnutrition, such as GE rice with high contents of vitamin A, are not accepted by the public. GE opponents have strongly resisted programs to provide subsistence farmers in Africa and Asia with GE "golden rice" that produces vitamin A precursor beta-carotene [11]. Our results clearly indicated that although most respondents generally would accept the use of GE algae for fuel production, some were concerned about the potential drawbacks and potential risks for nature. In contrast to their own more positive perception, many respondents consider the acceptance of the public to be much lower since they expect that there will be a significant share of people with low or no acceptance at all, mainly due to genetic engineering.

Our results do not indicate a significant difference in perception between genome editing and other techniques to modify microorganisms. Most respondents are not convinced that new techniques of genome editing significant increase acceptance for GE algae biofuel in the public. However, many of them are not aware of, and do not fully understand, genome editing and the differences in technology well enough to judge on this topic.

Some respondents are not convinced about the need to alter natural occurring algae strains to increase productivity since there is still a wide variety of natural algae strains to explore, and because the consequences of genome editing are unknown. Despite these concerns, the majority of the respondents would choose to be final consumers of GE algae biofuel.

The results of the survey indicate that, if conducive social and regulatory conditions are in place, it can substantially increase the positive impacts of GE algae biofuels on human welfare and sustainability. However more decisive benefits are required in order to convince the consumer to adopt algae biofuels, given their current high costs. 


\section{Conclusions}

There are numerous challenges in realizing the potential of algae biofuels envisioned by many policy-makers. The technical challenges to improve the sustainability of algae biofuel production to replace a significant fraction of transportation fuel have been well described. The use of genetic engineering can potentially address many of these technical challenges and environmental concerns, but brings significant regulatory hurdles that have not been discussed extensively in the scientific community. Additionally, concerns about and even rejection of algae biofuel could hamper market entrance if algae fuel is not able to keep the promises made. However, alongside the development of GE algae, social acceptance issues have been underestimated. While social acceptance can emerge as a powerful barrier for algae biofuel development, our results provide insights into their social acceptability. The results of the survey show how experts interpret the use of $\mathrm{GE}$ algae for the production of biofuels, and the values, beliefs and expectations that guide those interpretations, as well as the hopes and intentions interlinked with those fuels. Our findings show that gaining insights into the opinions of experts and stakeholders towards GE algae can contribute to developing feasible socio-technical algae systems for biofuel production and to (re-) design the processes and adapt the framework conditions towards a higher acceptability of GE microalgae. While this research is a helpful step in gathering an understanding of public attitudes toward genetically engineered algal biofuels, future research will need to examine a number of key issues in order to arrive at a more nuanced understanding of opinion formation for the algal biofuels issue.

\section{Methods}

\section{Questionnaire design and data collection}

Based on a literature review and interviews with experts on genetic engineering of microorganisms, we drafted the structure and content of a survey to be conducted online in order to facilitate the participation of people in European countries. A long list of European experts in the fields of microalgae, biofuels, genetics and environment, as well as of stakeholders, such as non-governmental organizations (NGOs), was compiled and reviewed, using the report on stakeholders produced in the project "Algae and aquatic biomass for a sustainable production of 2 nd generation biofuels-AquaFUELs" as the main source. A pre-test of the survey was conducted to verify the suitability of the questionnaire regarding its structure, comprehensibility and length. The online survey with the web-based questionnaire was performed using the platform www.soscisurvey.de. The experts and stakeholders were invited to participate via e-mail. In order to reach further experts and stakeholders and to increase the number of respondents, these persons were asked to forward the questionnaire to other experts and stakeholders from their fields of interest according to the snowballing approach discussed by Almeida et al. [2]. Further participants were recruited via professional business and research networks. The survey was conducted between September and November 2017.

The questionnaire comprised 16 (mainly closed) questions, which were structured into the following five sections.

1. Sociodemographic profile: gender, age, educational level, country of residence, experience in the algae industry and respective professional field.

2. Perceptions of expected benefits and risks of GE algae biofuel: opinions on the expected benefits of GE algae biofuel compared to fossil fuels, established biofuels and natural algae biofuels, as well as opinions on general risks of power sources used for mobility of the future.

3. Perceptions of social acceptance of GE algae biofuel: opinions about general social acceptance of GE algae biofuel in the EU, perceptions of how new geneediting techniques might improve public acceptance compared to classical genetic engineering techniques, and opinions about classifying and regulating gene-editing techniques as genetically modified organisms (GMOs).

4. Personal attitudes as consumers: attitudes towards becoming potential final consumers of GE algae biofuel, as well as the willingness to pay more money in cases of advantages regarding higher engine performances compared to established biofuels, or environmental advantages compared to fossil fuels.

5. Individual suggestions: opinions about how public acceptance of GE algae biofuel could be improved.

\section{Data analysis}

Data analysis was undertaken in two steps: (i) descriptive statistical analysis, and (ii) inductive statistical analysis. Descriptive statistical analysis was performed and presented by using Microsoft Excel ${ }^{\circledR}$ [22] and RStudio [25]. Inductive statistical analysis was performed by using IBM-SPSS.25 [12]. Figure 9 summarizes and gives an overview of the variables and the statistical tests 
performed to find relationships between them. All opinion ordinal variables were ranked in a 4 Point Likert scale [16].

Correlations between sociodemographic ordinal variables and opinion nominal variables were completed by using Spearman's rank correlation coefficient with SPSS software. The correlation coefficient can range in value from -1 to +1 . The larger the absolute value of the coefficient, the stronger the relationship between the variables. Due to the lack of a significant number of respondents from some countries, no inductive analysis was done for this variable; therefore no country-specific results are shown in this paper.

Correlations between sociodemographic variables and opinion nominal variables were done by using the Chi-square test of independence with SPSS software. Chi-square test shows if there is a significant relationship between variables, but it does not say how significant and important this is. Cramer's V is a post-test to give this additional information. In the cases where $p$ values obtained from Chi-tests were lower than 0.05 additional Cramer's V test was done in order to see the strength of the relationships. Cramer's V values were interpreted where: values $<0.10$ indicate weak relationships; values between 0.10 and 0.30 indicate moderate relationships, and values $>0.30$ indicate strong relationships. Fisher's test was done in cases of having two dichotomous categorical variables.

\section{Abbreviations}

TRL: Technology readiness level; GE: Genetically engineered; EROI: Energy return of investment; EU: European Union; NGO: Non-governmental organization; GMO: Genetically modified organism; GM: Genetically modified.

\section{Acknowledgements}

This study is supported by the European Union's Horizon 2020 research and innovation program under Grant agreement No 64072
Authors' contributions

JW designed the questionnaire, analyzed the data, and wrote the manuscript CB helped with the analysis of the data, and CR supervised the study. All

authors read and approved the final manuscript.

\section{Funding}

This study is supported by the European Union's Horizon 2020 research and innovation program under Grant agreement No. 64072.

\section{Availability of data and materials}

All data generated or analyzed during this study are included in this published article.

Ethics approval and consent to participate

This study is based on a survey answered by people anonymously, this declaration is not applicable.

\section{Consent for publication}

Not applicable.

\section{Competing interests}

The authors declare that they have no competing interests.

\section{Appendices}

\section{Appendix A}

Tables 4, 5, 6 and 7.

Table 4 Sociodemographic ordinal variables

\begin{tabular}{ll}
\hline Variable name & Answers \\
\hline Age & $<20$ years \\
& $20-30$ years \\
& $31-60$ years \\
& $>61$ years \\
& Did not complete high \\
Educational level & school \\
& High school \\
& Bachelor's degree \\
& Master's degree \\
& Other university degree \\
& PhD \\
& Never \\
Experience in algae industry & $<3$ years \\
& $3-10$ years \\
& $>10$ years \\
\hline
\end{tabular}




\section{Table 5 Opinion ordinal variables (4 Likert scale)}

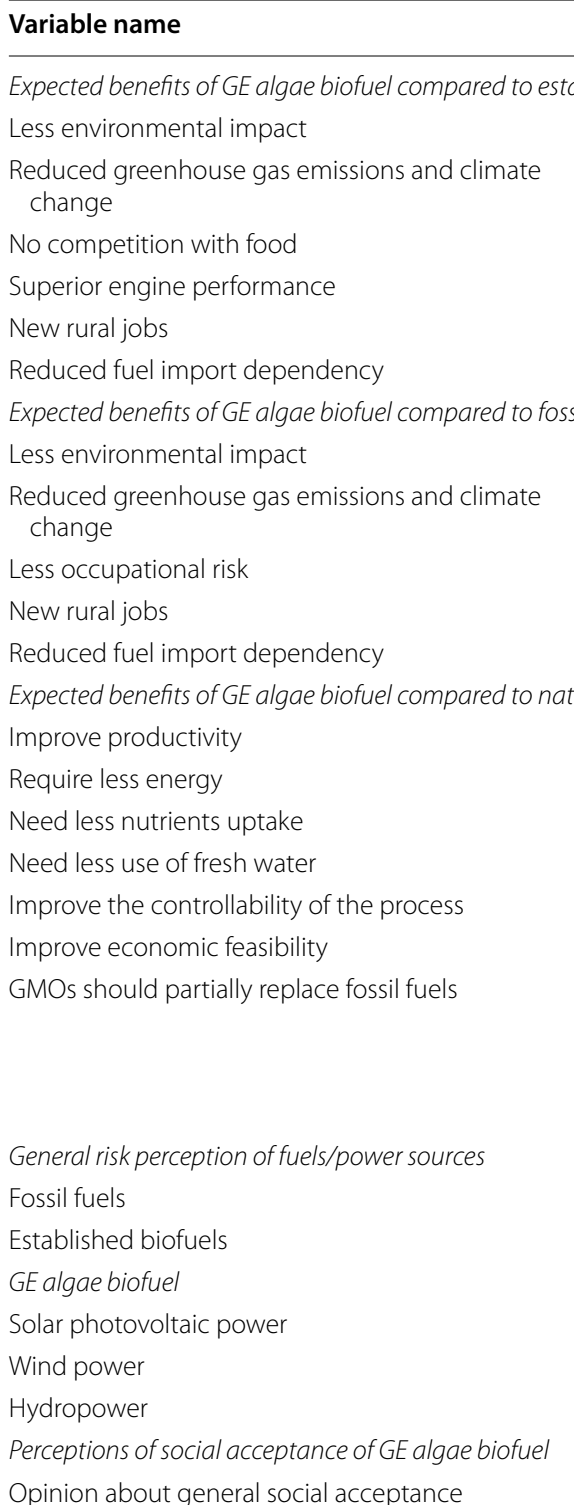

Variation of public acceptance in case of using
gene-editing techniques

Opinion about regulating gene-edited organisms as GMOs

\section{Answers}

shed biofuels

Totally not agree Rather not agree Rather agree

Totally agree

Do not know

\section{Table 6 Sociodemographic nominal variables}

\begin{tabular}{ll}
\hline Variable name & Answers \\
\hline Gender & Female \\
& Male \\
& Austria; Belgium; Bulgaria; Croatia; Cyprus; Czech \\
& Republic; Denmark; Estonia; Finland; France; \\
& Germany; Greece; Hungary; Ireland; Italy; Latvia; \\
& Lithuania; Luxembourg; Malta; Netherlands; Poland; \\
& Portugal; Romania; Slovakia; Slovenia; Spain; Sweden; \\
& United Kingdom \\
& Education/academia \\
& Industry/consulting/management \\
& Government \\
& Non-governmental organization \\
& Journalism \\
& Other
\end{tabular}

Totally not agree Rather not agree Rather agree Totally agree Do not know

Entirely harmless Rather harmless Rather alarming Entirely alarming Prefer not to answer

No acceptance Low Medium High acceptance Prefer not to answer

Lower

No difference Slightly higher Noticeably higher

Do not know

Totally not agree Rather not agree Rather agree Totally agree Prefer not to answer

\section{Table 7 Opinion nominal variables}

\begin{tabular}{|c|c|}
\hline Variable name & Answers \\
\hline \multicolumn{2}{|l|}{ Personal attitude as final consumer } \\
\hline $\begin{array}{l}\text { Opinion about being final consumer of GE algae } \\
\text { biofuel }\end{array}$ & $\begin{array}{l}\text { Yes } \\
\text { No } \\
\text { Do not know }\end{array}$ \\
\hline $\begin{array}{l}\text { Willingness to pay more money if higher engine } \\
\text { performances were achieved compared to estab- } \\
\text { lished biofuels }\end{array}$ & $\begin{array}{l}\text { Yes, }<5 \% \\
\text { Yes, } 5-10 \% \text { more } \\
\text { Yes, } 10-20 \% \text { more }\end{array}$ \\
\hline $\begin{array}{l}\text { Willingness to pay more money if environmental } \\
\text { advantages were achieved compared to fossil } \\
\text { fuels }\end{array}$ & $\begin{array}{l}\text { Yes, }>20 \% \\
\text { Yes, do not know } \\
\text { how much more } \\
\text { No }\end{array}$ \\
\hline \multicolumn{2}{|l|}{ Suggestions to improve general social acceptance } \\
\hline $\begin{array}{l}\text { Regulations before any genome engineered species } \\
\text { is implemented }\end{array}$ & $\begin{array}{l}\text { Yes } \\
\text { No }\end{array}$ \\
\hline \multicolumn{2}{|l|}{$\begin{array}{l}\text { Higher or same economic benefits than using fossil } \\
\text { fuels }\end{array}$} \\
\hline \multicolumn{2}{|l|}{ Clear evidence of benefits } \\
\hline \multicolumn{2}{|l|}{$\begin{array}{l}\text { Clear communication of risks and benefits of } \\
\text { genome engineering technologies }\end{array}$} \\
\hline \multicolumn{2}{|l|}{$\begin{array}{l}\text { Rigorous risk assessments of GM algae, involving } \\
\text { scientists with minimal conflicts of interest, inde- } \\
\text { pendent peer review, and public participation }\end{array}$} \\
\hline \multicolumn{2}{|l|}{$\begin{array}{l}\text { Closed production systems with high security } \\
\text { standards }\end{array}$} \\
\hline \multicolumn{2}{|l|}{ Use of genetic markers } \\
\hline \multicolumn{2}{|l|}{ Minor survivability compared to natural strains } \\
\hline $\begin{array}{l}\text { Use of new precise gene editing tools instead of } \\
\text { traditional genome engineering }\end{array}$ & \\
\hline
\end{tabular}

\section{Appendix B}

Tables 8, 9, 10 and 11. 
Table $8 p$ values after Spearman's rank order correlation coefficients between sociodemographic ordinal variables (Appendix A: Table 4) and opinion ordinal variables (Appendix A: Table 5)

\begin{tabular}{|c|c|c|c|}
\hline Sociodemographic ordinal variables & Opinion ordinal variables & $\begin{array}{l}\text { Spearman's rank } \\
\text { order coefficient }\end{array}$ & $p$ value \\
\hline \multirow[t]{32}{*}{ Age } & Expected benefits of GE algae biofuel compared to established biofuels & & \\
\hline & Less environmental impact & -0.17 & 0.025 \\
\hline & Reduced GHG emissions and climate change & -0.19 & 0.023 \\
\hline & No competition with food & -0.02 & 0.915 \\
\hline & Superior engine performance & -0.09 & 0.268 \\
\hline & New rural jobs & -0.13 & 0.389 \\
\hline & Reduced fuel import dependency & 0.03 & 0.637 \\
\hline & Expected benefits of GE algae biofuel compared to fossil fuels & & \\
\hline & Less environmental impact & -0.05 & 0.345 \\
\hline & Reduced GHG emissions and climate change & -0.05 & 0.391 \\
\hline & Less occupational risk & -0.25 & 0.326 \\
\hline & New rural jobs & -0.06 & 0.807 \\
\hline & Reduced fuel import dependency & -0.02 & 0.949 \\
\hline & Expected benefits of GE algae biofuel compared to natural strains & & \\
\hline & Improve productivity & -0.23 & 0.148 \\
\hline & Require less energy & -0.23 & 0.109 \\
\hline & Need less nutrients uptake & -0.18 & 0.326 \\
\hline & Need less use of fresh water & -0.08 & 0.902 \\
\hline & Improve the controllability of the process & -0.2 & 0.355 \\
\hline & Improve economic feasibility & -0.19 & 0.554 \\
\hline & GMOs should partially replace fossil fuels & -0.02 & 0.255 \\
\hline & Perceptions of social acceptance of GE algae biofuel & & \\
\hline & Opinion about general social acceptance & -0.15 & 0.167 \\
\hline & Variation of public acceptance in case of using gene-editing techniques & -0.04 & 0.662 \\
\hline & Opinion about regulating gene-edited organisms as GMOs & 0.09 & 0.665 \\
\hline & General risk perception of fuels/power sources & & \\
\hline & Fossil fuels & 0.06 & 0.528 \\
\hline & Established biofuels & 0.01 & 0.858 \\
\hline & GE algae biofuel & 0.06 & 0.972 \\
\hline & Solar photovoltaic power & 0.06 & 0.851 \\
\hline & Wind power & 0.07 & 0.907 \\
\hline & Hydropower & -0.02 & 0.897 \\
\hline \multirow[t]{16}{*}{ Educational level } & Expected benefits of GE algae biofuel compared to established biofuels & & \\
\hline & Less environmental impact & 0.02 & 0.044 \\
\hline & Reduced GHG emissions and climate change & -0.03 & 0.001 \\
\hline & No competition with food & 0.12 & 0.058 \\
\hline & Superior engine performance & -0.04 & 0.314 \\
\hline & New rural jobs & 0.06 & 0.040 \\
\hline & Reduced fuel import dependency & -0.02 & 0.126 \\
\hline & Expected benefits of GE algae biofuel compared to fossil fuels & & \\
\hline & Less environmental impact & 0.04 & 0.158 \\
\hline & Reduced GHG emissions and climate change & -0.06 & 0.085 \\
\hline & Less occupational risk & -0.08 & 0.619 \\
\hline & New rural jobs & 0.02 & 0.068 \\
\hline & Reduced fuel import dependency & -0.13 & 0.071 \\
\hline & Expected benefits of GE algae biofuel compared to natural strains & & \\
\hline & Improve productivity & 0.01 & 0.598 \\
\hline & Require less energy & -0.03 & 0.021 \\
\hline
\end{tabular}


Table 8 (continued)

\begin{tabular}{|c|c|c|c|}
\hline Sociodemographic ordinal variables & Opinion ordinal variables & $\begin{array}{l}\text { Spearman's rank } \\
\text { order coefficient }\end{array}$ & $p$ value \\
\hline & Need less nutrients uptake & 0.06 & 0.696 \\
\hline & Need less use of fresh water & 0.03 & 0.860 \\
\hline & Improve the controllability of the process & -0.06 & 0.321 \\
\hline & Improve economic feasibility & -0.05 & 0.313 \\
\hline & GMOs should partially replace fossil fuels & -0.02 & 0.420 \\
\hline & Perceptions of social acceptance of GE algae biofuel & & \\
\hline & Opinion about general social acceptance & -0.09 & 0.927 \\
\hline & Variation of public acceptance in case of using gene-editing techniques & 0.04 & 0.776 \\
\hline & Opinion about regulating gene-edited organisms as GMOs & 0.06 & 0.216 \\
\hline & General risk perception of fuels/power sources & & \\
\hline & Fossil fuels & -0.08 & 0.933 \\
\hline & Established biofuels & 0.05 & 0.740 \\
\hline & GE algae biofuel & -0.07 & 0.335 \\
\hline & Solar photovoltaic power & 0.04 & 0.637 \\
\hline & Wind power & -0.15 & 0.780 \\
\hline & Hydropower & -0.16 & 0.086 \\
\hline \multirow{32}{*}{ Experience in algae industry } & Expected benefits of GE algae biofuel compared to established biofuels & & \\
\hline & Less environmental impact & 0 & 0.927 \\
\hline & Reduced GHG emissions and climate change & -0.11 & 0.659 \\
\hline & No competition with food & 0.01 & 0.397 \\
\hline & Superior engine performance & -0.01 & 0.624 \\
\hline & New rural jobs & -0.06 & 0.828 \\
\hline & Reduced fuel import dependency & 0.03 & 0.727 \\
\hline & Expected benefits of GE algae biofuel compared to fossil fuels & & \\
\hline & Less environmental impact & -0.11 & 0.560 \\
\hline & Reduced GHG emissions and climate change & -0.11 & 0.822 \\
\hline & Less occupational risk & 0.04 & 0.928 \\
\hline & New rural jobs & -0.01 & 0.989 \\
\hline & Reduced fuel import dependency & -0.02 & 0.977 \\
\hline & Expected benefits of GE algae biofuel compared to natural strains & & \\
\hline & Improve productivity & -0.06 & 0.416 \\
\hline & Require less energy & 0.03 & 0.488 \\
\hline & Need less nutrients uptake & -0.04 & 0.256 \\
\hline & Need less use of fresh water & 0.08 & 0.107 \\
\hline & Improve the controllability of the process & -0.06 & 0.953 \\
\hline & Improve economic feasibility & -0.15 & 0.174 \\
\hline & GMOs should partially replace fossil fuels & 0.04 & 0.366 \\
\hline & Perceptions of social acceptance of GE algae biofuel & & \\
\hline & Opinion about general social acceptance & 0 & 0.657 \\
\hline & Variation of public acceptance in case of using gene-editing techniques & 0.02 & 0.666 \\
\hline & Opinion about regulating gene-edited organisms as GMOs & -0.02 & 0.410 \\
\hline & General risk perception of fuels/power sources & & \\
\hline & Fossil fuels & -0.09 & 0.450 \\
\hline & Established biofuels & -0.02 & 0.951 \\
\hline & GE algae biofuel & -0.02 & 0.784 \\
\hline & Solar photovoltaic power & -0.02 & 0.714 \\
\hline & Wind power & -0.03 & 0.808 \\
\hline & Hydropower & -0.06 & 0.835 \\
\hline
\end{tabular}


Table 9 Chi-square test $p$ values between sociodemographic nominal variables (Appendix A: Table 6) and opinion nominal variables (Appendix A: Table 7)

\begin{tabular}{|c|c|c|c|}
\hline $\begin{array}{l}\text { Sociodemographic } \\
\text { nominal variables }\end{array}$ & Opinion nominal variables & $\mathrm{Chi}^{2} p$ value & $\begin{array}{l}\text { Fisher's } \\
\text { test } p \\
\text { value }\end{array}$ \\
\hline \multirow[t]{15}{*}{ Gender } & Personal attitude as final consumer & & \\
\hline & Opinion about being final consumer of GE algae biofuel & 0.467 & \\
\hline & $\begin{array}{l}\text { Willingness to pay more money if higher engine performances were achieved compared to estab- } \\
\text { lished biofuels }\end{array}$ & 0.959 & \\
\hline & Willingness to pay more money if environmental advantages were achieved compared to fossil fuels & 0.504 & \\
\hline & Suggestions to improve general social acceptance & & \\
\hline & Regulations before any genome engineered species is implemented & 0.091 & 0.144 \\
\hline & Higher or same economic benefits than using fossil fuels & 0.774 & 0.824 \\
\hline & Clear evidence of benefits use of genetic markers & 0.479 & 0.516 \\
\hline & Clear communication of risks and benefits of genome engineering technologies & 0.983 & 1.000 \\
\hline & $\begin{array}{l}\text { Rigorous risk assessments of GM algae, involving scientists with minimal conflicts of interest, inde- } \\
\text { pendent peer review, and public participation }\end{array}$ & 0.079 & 0.122 \\
\hline & Closed production systems with high security standards & 0.217 & 0.268 \\
\hline & Use of genetic markers & 0.132 & 0.193 \\
\hline & Minor survivability compared to natural strains & 0.665 & 0.818 \\
\hline & Use of new precise gene editing tools instead of traditional genome engineering & 0.224 & 0.256 \\
\hline & Regulations before any genome engineered species is implemented & 0.055 & 0.069 \\
\hline \multirow[t]{15}{*}{ Working field } & Personal attitude as final consumer & & \\
\hline & Opinion about being final consumer of GE algae biofuel & 0.910 & \\
\hline & $\begin{array}{l}\text { Willingness to pay more money if higher engine performances were achieved compared to estab- } \\
\text { lished biofuels }\end{array}$ & 0.757 & \\
\hline & Willingness to pay more money if environmental advantages were achieved compared to fossil fuels & 0.637 & \\
\hline & Suggestions to improve general social acceptance & & \\
\hline & Regulations before any genome engineered species is implemented & 0.389 & \\
\hline & Higher or same economic benefits than using fossil fuels & 0.375 & \\
\hline & Clear evidence of benefits use of genetic markers & 0.184 & \\
\hline & Clear communication of risks and benefits of genome engineering technologies & 0.931 & \\
\hline & $\begin{array}{l}\text { Rigorous risk assessments of GM algae, involving scientists with minimal conflicts of interest, inde- } \\
\text { pendent peer review, and public participation }\end{array}$ & 0.922 & \\
\hline & Closed production systems with high security standards & 0.753 & \\
\hline & Use of genetic markers & 0.900 & \\
\hline & Minor survivability compared to natural strains & 0.136 & \\
\hline & Use of new precise gene editing tools instead of traditional genome engineering & 0.500 & \\
\hline & Regulations before any genome engineered species is implemented & 0.304 & \\
\hline
\end{tabular}

Fisher's test was done in cases of having two dichotomous categorical variables 
Table 10 Chi-square test $p$ values between sociodemographic ordinal variables (Appendix A: Table 4) and opinion nominal variables (Appendix A: Table 7)

\begin{tabular}{|c|c|c|c|}
\hline $\begin{array}{l}\text { Sociodemographic } \\
\text { ordinal variables }\end{array}$ & Opinion nominal variables & $p$ value & Cramer's V \\
\hline \multirow[t]{15}{*}{ Age } & Personal attitude as final consumer & & \\
\hline & Opinion about being final consumer of GE algae biofuel & 0.422 & \\
\hline & Willingness to pay more money if higher engine performances were achieved compared to established biofuels & 0.512 & \\
\hline & Willingness to pay more money if environmental advantages were achieved compared to fossil fuels & 0.724 & \\
\hline & Suggestions to improve general social acceptance & & \\
\hline & Regulations before any genome engineered species is implemented & 0.152 & \\
\hline & Higher or same economic benefits than using fossil fuels & 0.985 & \\
\hline & Clear evidence of benefits use of genetic markers & 0.771 & \\
\hline & Clear communication of risks and benefits of genome engineering technologies & 0.372 & \\
\hline & $\begin{array}{l}\text { Rigorous risk assessments of GM algae, involving scientists with minimal conflicts of interest, independent peer } \\
\text { review, and public participation }\end{array}$ & 0.485 & \\
\hline & Closed production systems with high security standards & 0.041 & 0.221 \\
\hline & Use of genetic markers & 0.914 & \\
\hline & Minor survivability compared to natural strains & 0.945 & \\
\hline & Use of new precise gene editing tools instead of traditional genome engineering & 0.044 & 0.220 \\
\hline & Regulations before any genome engineered species is implemented & 0.180 & \\
\hline \multirow[t]{15}{*}{ Educational level } & Personal attitude as final consumer & & \\
\hline & Opinion about being final consumer of GE algae biofuel & 0.037 & 0.251 \\
\hline & Willingness to pay more money if higher engine performances were achieved compared to established biofuels & 0.580 & \\
\hline & Willingness to pay more money if environmental advantages were achieved compared to fossil fuels & 0.651 & \\
\hline & Suggestions to improve general social acceptance & & \\
\hline & Regulations before any genome engineered species is implemented & 0.565 & \\
\hline & Higher or same economic benefits than using fossil fuels & 0.188 & \\
\hline & Clear evidence of benefits use of genetic markers & 0.325 & \\
\hline & Clear communication of risks and benefits of genome engineering technologies & 0.004 & 0.346 \\
\hline & $\begin{array}{l}\text { Rigorous risk assessments of GM algae, involving scientists with minimal conflicts of interest, independent peer } \\
\text { review, and public participation }\end{array}$ & 0.662 & \\
\hline & Closed production systems with high security standards & 0.467 & \\
\hline & Use of genetic markers & 0.915 & \\
\hline & Minor survivability compared to natural strains & 0.045 & \\
\hline & Use of new precise gene editing tools instead of traditional genome engineering & 0.855 & \\
\hline & Regulations before any genome engineered species is implemented & 0.184 & \\
\hline \multirow{15}{*}{$\begin{array}{l}\text { Experience in algae } \\
\text { industry }\end{array}$} & Personal attitude as final consumer & & \\
\hline & Opinion about being final consumer of GE algae biofuel & 0.024 & 0.236 \\
\hline & Willingness to pay more money if higher engine performances were achieved compared to established biofuels & 0.078 & - \\
\hline & Willingness to pay more money if environmental advantages were achieved compared to fossil fuels & 0.458 & - \\
\hline & Suggestions to improve general social acceptance & & \\
\hline & Regulations before any genome engineered species is implemented & 0.912 & \\
\hline & Higher or same economic benefits than using fossil fuels & 0.988 & \\
\hline & Clear evidence of benefits use of genetic markers & 0.339 & \\
\hline & Clear communication of risks and benefits of genome engineering technologies & 0.822 & \\
\hline & $\begin{array}{l}\text { Rigorous risk assessments of GM algae, involving scientists with minimal conflicts of interest, independent peer } \\
\text { review, and public participation }\end{array}$ & 0.562 & \\
\hline & Closed production systems with high security standards & 0.412 & \\
\hline & Use of genetic markers & 0.672 & \\
\hline & Minor survivability compared to natural strains & 0.734 & \\
\hline & Use of new precise gene editing tools instead of traditional genome engineering & 0.353 & \\
\hline & Regulations before any genome engineered species is implemented & 0.749 & \\
\hline
\end{tabular}


Table 11 Chi-square test $p$ values between sociodemographic nominal variables (Appendix A: Table 6) and opinion ordinal values (Appendix A: Table 6)

\begin{tabular}{|c|c|c|c|}
\hline $\begin{array}{l}\text { Sociodemographic nominal } \\
\text { variables }\end{array}$ & Opinion ordinal variables & $p$ value & Cramer's V \\
\hline \multirow[t]{32}{*}{ Gender } & Expected benefits of GE algae biofuel compared to established biofuels & & \\
\hline & Less environmental impact & 0.281 & \\
\hline & Reduced GHG emissions and climate change & 0.492 & \\
\hline & No competition with food & 0.773 & \\
\hline & Superior engine performance & 0.778 & \\
\hline & New rural jobs & 0.866 & \\
\hline & Reduced fuel import dependency & 0.973 & \\
\hline & Expected benefits of GE algae biofuel compared to fossil fuels & & \\
\hline & Less environmental impact & 0.412 & \\
\hline & Reduced GHG emissions and climate change & 0.800 & \\
\hline & Less occupational risk & 0.639 & \\
\hline & New rural jobs & 0.302 & \\
\hline & Reduced fuel import dependency & 0.143 & \\
\hline & Expected benefits of GE algae biofuel compared to natural strains & & \\
\hline & Improve productivity & 0.299 & \\
\hline & Require less energy & 0.413 & \\
\hline & Need less nutrients uptake & 0.408 & \\
\hline & Need less use of fresh water & 0.863 & \\
\hline & Improve the controllability of the process & 0.920 & \\
\hline & Improve economic feasibility & 0.686 & \\
\hline & GMOs should partially replace fossil fuels & 0.382 & \\
\hline & Perceptions of social acceptance of GE algae biofuel & & \\
\hline & Opinion about general social acceptance & 0.129 & \\
\hline & Variation of public acceptance in case of using gene-editing techniques & 0.177 & \\
\hline & Opinion about regulating gene-edited organisms as GMOs & 0.256 & \\
\hline & General risk perception of fuels/power sources & & \\
\hline & Fossil fuels & 0.770 & \\
\hline & Established biofuels & 0.144 & \\
\hline & GE algae biofuel & 0.536 & \\
\hline & Solar photovoltaic power & 0.358 & \\
\hline & Wind power & 0.887 & \\
\hline & Hydropower & 0.034 & 0.285 \\
\hline \multirow[t]{14}{*}{ Working field } & Expected benefits of GE algae biofuel compared to established biofuels & & \\
\hline & Less environmental impact & 0.926 & \\
\hline & Reduced GHG emissions and climate change & 0.993 & \\
\hline & No competition with food & 0.011 & 0.246 \\
\hline & Superior engine performance & 0.822 & \\
\hline & New rural jobs & 0.132 & \\
\hline & Reduced fuel import dependency & 0.443 & \\
\hline & Expected benefits of GE algae biofuel compared to fossil fuels & & \\
\hline & Less environmental impact & 0.750 & \\
\hline & Reduced GHG emissions and climate change & 0.981 & \\
\hline & Less occupational risk & 0.200 & \\
\hline & New rural jobs & 0.802 & \\
\hline & Reduced fuel import dependency & 0.786 & \\
\hline & Expected benefits of GE algae biofuel compared to natural strains & & \\
\hline
\end{tabular}


Table 11 (continued)

\begin{tabular}{|c|c|c|c|}
\hline $\begin{array}{l}\text { Sociodemographic nominal } \\
\text { variables }\end{array}$ & Opinion ordinal variables & $p$ value & Cramer's V \\
\hline & Improve productivity & 0.276 & \\
\hline & Require less energy & 0.016 & 0.242 \\
\hline & Need less nutrients uptake & 0.138 & \\
\hline & Need less use of fresh water & 0.286 & \\
\hline & Improve the controllability of the process & 0.050 & 0.225 \\
\hline & Improve economic feasibility & 0.138 & \\
\hline & GMOs should partially replace fossil fuels & 0.634 & \\
\hline & Perceptions of social acceptance of GE algae biofuel & & \\
\hline & Opinion about general social acceptance & 0.843 & \\
\hline & Variation of public acceptance in case of using gene-editing techniques & 0.720 & \\
\hline & Opinion about regulating gene-edited organisms as GMOs & 0.024 & 0.236 \\
\hline & General risk perception of fuels/power sources & & \\
\hline & Fossil fuels & 0.022 & 0.237 \\
\hline & Established biofuels & 0.238 & \\
\hline & GE algae biofuel & 0.126 & \\
\hline & Solar photovoltaic power & 0.056 & 0.230 \\
\hline & Wind power & 0.002 & 0.267 \\
\hline & Hydropower & 0.427 & \\
\hline
\end{tabular}

Cramer's V values were calculated only in cases where $p$ values $<0.05$

Received: 10 September 2019 Accepted: 12 May 2020

Published online: 22 May 2020

\section{References}

1. Adeniyi OM, Azimov U, Burluka A. Algae biofuel: current status and future applications. Renew Sustain Energy Rev. 2018;90:316-35.

2. Almeida I, Rösch C, Saha S. Comparison of ecosystem services from mixed and monospecific forests in southwest Germany: a survey on public perception. Forests. 2018;9:10.

3. Barsanti L, Gualtieri P. Is exploitation of microalgae economically and energetically sustainable? Algal Res. 2018;31:107-15.

4. Beacham TA, Sweet JB, Allen MJ. Large scale cultivation of genetically modified microalgae: a new era for environmental risk assessment. Algal Res. 2017;25:90-100.

5. Christiansen AT, Andersen MM, Kappel K. Are current EU policies on GMOs justified? Transgenic Res. 2019;28(2):267-86.

6. Crozet P, Navarro FJ, Willmund F, Mehrshahi P, Bakowski K, Lauersen KJ Pérez-Pérez M-E, Auroy P, Gorchs Rovira A, Sauret-Gueto S, Niemeyer J Spaniol B, Theis J, Trösch R, Westrich L-D, Vavitsas K, Baier T, Hübner W, de Carpentier F, Cassarini M, Danon A, Henri J, Marchand CH, de Mia M, Sarkissian K, Baulcombe DC, Peltier G, Crespo JL, Kruse O, Jensen PE, Schroda M, Smith AG, Lemaire SD. Birth of a photosynthetic chassis: a MoClo toolkit enabling synthetic biology in the microalga Chlamydomonas reinhardtii. ACS Synth Biol. 2018;7(9):2074-86.

7. Efroymson RA, Dale VH, Langholtz MH. Socioeconomic indicators for sustainable design and commercial development of algal biofuel systems. GCB Bioenergy. 2017:9(6):1005-23.

8. Einsiedel E, Eastlick D. Consensus conferences as deliberative democracy. Sci Commun. 2000;21(4):323-43.

9. Frewer $L J$, van der Lans IA, Fischer ARH, Reinders MJ, Menozzi D, Zhang $X Y$, van den Berg I, Zimmermann KL. Public perceptions of agri-food applications of genetic modification - A systematic review and metaanalysis. Trends Food Sci Technol. 2013;30(2):142-52.

10. Galarza Jl, Delgado N, Henriquez V. Cisgenesis and intragenesis in microalgae: promising advancements towards sustainable metabolites production. Appl Microbiol Biotechnol. 2016;100(24):10225-35.

11. Harmon A. Golden rice: lifesaver. The New York Times:; 2013. p. 24

12. IBM SPSS Statistics for Windows, Version 25.0. IBM Corp. Released 2017. Armonk: IBM Corp.

13. Ketzer F, Skarka J, Rösch C. Critical Review of Microalgae LCA Studies for Bioenergy Production. BioEnergy Research. 2018;11(1):95-105.

14. Kubik, M., 2006. Consumer Views on Transportation and Energy. http:// www.nrel.gov/docs/fy06osti/39047.pdf. Accessed 01 Feb 06.

15. Lam FH, Ghaderi A, Fink GR, Stephanopoulos G. Engineering alcohol tolerance in yeast. Yeast. 2015:32:S45.

16. Likert R. A technique for the measurement of attitudes. New York: The Science Press; 1932

17. Lucht JM. Public Acceptance of Plant Biotechnology and GM Crops Viruses-Basel. 2015;7(8):4254-81.

18. Malaquias ACT, Netto NAD, Rodrigues Filho FA, da Costa RBR, Langeani $M$, Baêta JGC. The misleading total replacement of internal combustion engines by electric motors and a study of the Brazilian ethanol importance for the sustainable future of mobility: a review. J Braz Soc Mech Sci Eng. 2019;41(12):567.

19. Miao R, Liu X, Englund E, Lindberg P, Lindblad P. Isobutanol production in Synechocystis PCC 6803 using heterologous and endogenous alcohol dehydrogenases. Metab Eng Commun. 2017;5:45-53.

20. Miao R, Xie H, Ho FM, Lindblad P. Protein engineering of a-ketoisovalerate decarboxylase for improved isobutanol production in Synechocystis PCC 6803. Metab Eng. 2018:47:42-8.

21. Miao R. Metabolic engineering of synechocystis PCC 6803 for butanol production (PhD dissertation). Uppsala. 2018. Retrieved from http://urn. kb.se/resolve?urn=urn:nbn:se:uu:diva-360031.

22. Microsoft Excel ${ }^{\circledR} 2013$, one component of Microsoft Office Professional Plus (2013). 
23. Moula MEM, Nyári J, Bartel A. Public acceptance of biofuels in the transport sector in Finland. Int J Sustain Built Environ. 2017;6(2):434-41.

24. Pankratz S, Oyedun AO, Kumar A. Development of cost models of algae production in a cold climate using different production systems. Biofuels Bioprod Biorefin. 2019;13(5):1246-60.

25. R Studio Team, 2012. RStudio. RStudio, Boston, MA, http://www.rstud io.org/.

26. Radakovits R, Jinkerson RE, Darzins A, Posewitz MC. Genetic Engineering of Algae for Enhanced Biofuel Production. Eukaryot Cell. 2010;9(4):486-501.

27. Rogers EM. Diffusion of preventive innovations. Addict Behav. 2002;27(6):989-93.

28. Rösch C, Rossmann M, Weickert S. Microalgae for integrated food and fuel production. Global Change Biol Bioenergy. 2019;11(1):326-34.

29. Schenk PM, Thomas-Hall SR, Stephens E, Marx UC, Mussgnug JH, Posten C, Kruse O, Hankamer B. Second generation biofuels: high-efficiency microalgae for biodiesel production. BioEnergy Res. 2008;1(1):20-43.

30. Scott SE, Inbar Y, Rozin P. Evidence for absolute moral opposition to genetically modified food in the United States. Perspect Psychol Sci. 2016;11(3):315-24.

31. Sticklen MB. Plant genetic engineering for biofuel production: towards affordable cellulosic ethanol. Nat Rev Genet. 2008;9(6):433-43.

32. Thornley P, Gilbert P. Biofuels: balancing risks and rewards. Interface Focus. 2013;3(1):20120040.
33. Tredici MR, Bassi N, Prussi M, Biondi N, Rodolfi L, Zittelli GC, Sampietro G. Energy balance of algal biomass production in a 1-ha "Green Wall Panel" plant: how to produce algal biomass in a closed reactor achieving a high Net Energy Ratio. Appl Energy. 2015;154:1103-11.

34. Wang QT, Lu YD, Xin Y, Wei L, Huang S, Xu J. Genome editing of model oleaginous microalgae Nannochloropsis spp. by CRISPR/Cas9. Plant Journal. 2016;88(6):1071-81.

35. Wegener DT, Kelly JR. Social psychological dimensions of bioenergy development and public acceptance. Bioenergy Research. 2008;1(2):107-17.

36. Wichmann J, Baier T, Wentnagel E, Lauersen KJ, Kruse O. Tailored carbon partitioning for phototrophic production of (E)-a-bisabolene from the green microalga Chlamydomonas reinhardtii. Metab Eng. 2018;45:211-22.

37. Yunus IS, Wichmann J, Wördenweber R, Lauersen KJ, Kruse O, Jones PR. Synthetic metabolic pathways for photobiological conversion of $\mathrm{CO}_{2}$ into hydrocarbon fuel. Metab Eng. 2018;49:201-11.

38. Zavřel T, Szabó M, Tamburic B, Evenhuis C, Kuzhiumparambil U, Literáková P, Larkum AWD, Raven JA, Červený J, Ralph PJ. Effect of carbon limitation on photosynthetic electron transport in Nannochloropsis oculata. J Photochem Photobiol B. 2018;181:31-43.

\section{Publisher's Note}

Springer Nature remains neutral with regard to jurisdictional claims in published maps and institutional affiliations.
Ready to submit your research? Choose BMC and benefit from:

- fast, convenient online submission

- thorough peer review by experienced researchers in your field

- rapid publication on acceptance

- support for research data, including large and complex data types

- gold Open Access which fosters wider collaboration and increased citations

- maximum visibility for your research: over 100M website views per year

At BMC, research is always in progress.

Learn more biomedcentral.com/submissions 